\title{
Effects of prostaglandin F-2 $\alpha$ and E-2 on the production of progesterone by mouse ovaries in vitro
}

\author{
P. Neal, T. G. Baker and K. P. McNatty* \\ Hormone Laboratory, Department of Obstetrics and Gynaecology, University of Edinburgh, and \\ *M.R.C. Unit of Reproductive Biology, 39 Chalmers Street, Edinburgh, EH3 9ER, U.K.
}

Numerous studies have shown that prostaglandin (PG) E-2 can stimulate ovarian steroidogenesis in vitro and can mimic many of the actions of $\mathrm{LH}$ on the Graafian follicle in vivo and in vitro (see Neal, Baker, McNatty \& Scaramuzzi, 1975). Paradoxically, however, PGF-2 $\alpha$ can stimulate or inhibit steroidogenesis by ovarian follicles or isolated cells in vitro, the response varying with the dose employed.

Many of these diverse actions of PGs may be the result of using pharmacological rather than physiological doses of the drugs (see McNatty, Henderson \& Sawers, 1975; Neal et al., 1975). In the present investigation, therefore, the effects of various doses of PGE-2 and PGF-2 $\alpha$, alone and in combination, on the secretion of progesterone by mouse ovaries in vitro, with or without added gonadotrophins, were examined.

Mice of the Schofield albino strain (aged 27 days) were given an i.p. injection of 4 i.u. PMSG (Gestyl: Organon Laboratories). The animals were killed $48 \mathrm{hr}$ later and the ovaries were removed for culture in the system of Neal et al. (1975). However, to minimize the quantities of gonadotrophins and prostaglandins required, each ovary was cultured in a $30-\mathrm{mm}$ disposable Petri dish containing $1 \mathrm{ml}$ of the nutrient medium (Eagle's minimal essential medium $+20 \%$ calf serum). The concentration of LH in the culture medium was $<5$ ng equivalents of NIH-LH-S14/ml, and that for PGF- $2 \alpha$ and PGE-2 was $<0 \cdot 1 \mathrm{ng}$ and $<0 \cdot 2 \mathrm{ng} / \mathrm{ml}$ respectively (see McNatty \& Sawers, 1975): FSH was not determined.

Ovaries in the control group were maintained in culture medium without added gonadotrophins or prostaglandins. Further groups (each containing 7 ovaries) were incubated for $24 \mathrm{hr}$ in medium to which was added $1 \mu \mathrm{g}$ NIH-LH-S18/ml $+1 \mu \mathrm{g}$ NIH-FSH-S9/ml and/or PGs (dissolved in Eagle's medium), which were added to the Petri dishes at a final concentration of $10,50,500$ or $1000 \mathrm{ng} / \mathrm{ml}$. Twenty-four hours after the onset of culture, the ovarian explants were fixed in Bouin's aqueous fluid for subsequent histology and the media stored at $-18^{\circ} \mathrm{C}$ before radioimmunoassay for progesterone (see Neal et al., 1975).

Increasing doses of PGE-2 significantly enhanced the production of progesterone $(r=0.62$, $P<0.001$ ) in a linear fashion (Text-fig. 1a). Regression analysis of these results gave the equation, $y=0 \cdot 1 x+44$, where $x$ is the concentration of PGE-2 in $\mathrm{ng} / \mathrm{ml}$ and $y$ is the concentration of progesterone in $\mathrm{ng} / \mathrm{ml}$. By contrast PGF- $2 \alpha$ did not enhance the production of progesterone above control levels. The addition of the combined preparation (10 or $1000 \mathrm{ng}$ each $\mathrm{PG} / \mathrm{ml}$ ) resulted in a level of progesterone similar to that when PGE-2 was used alone. When the explants were exposed to $\mathrm{LH}+\mathrm{FSH}(1 \mu \mathrm{g}$ each), the addition of PGE-2 did not significantly enhance the production of progesterone except at the highest dose (Text-fig. 1b), but PGF-2 $\alpha$ at the lowest dose caused a significant decrease in the production of progesterone $(P<0.01)$ and at the highest dose caused a significant increase $(P<0.01)$. Progesterone production after addition of both $P G s$ was similar to that after stimulation by PGE-2 + LH + FSH.

These results demonstrate that PGE-2, even at seemingly low concentration, can stimulate the production of progesterone by mouse ovaries in vitro, confirming earlier studies with non-physiological doses (Lindner et al., 1974a, b; Neal et al., 1975). The present studies also show that PGF-2 $\alpha$ has little effect on steroidogenesis when the tissue is producing little or no progesterone. When ovarian tissue is exposed to gonadotrophins which stimulate progesterone secretion, however, low doses of PGF-2 $\alpha$ partly blocked the stimulatory effect of LH + FSH $(50 \%)$ while high doses enhanced 


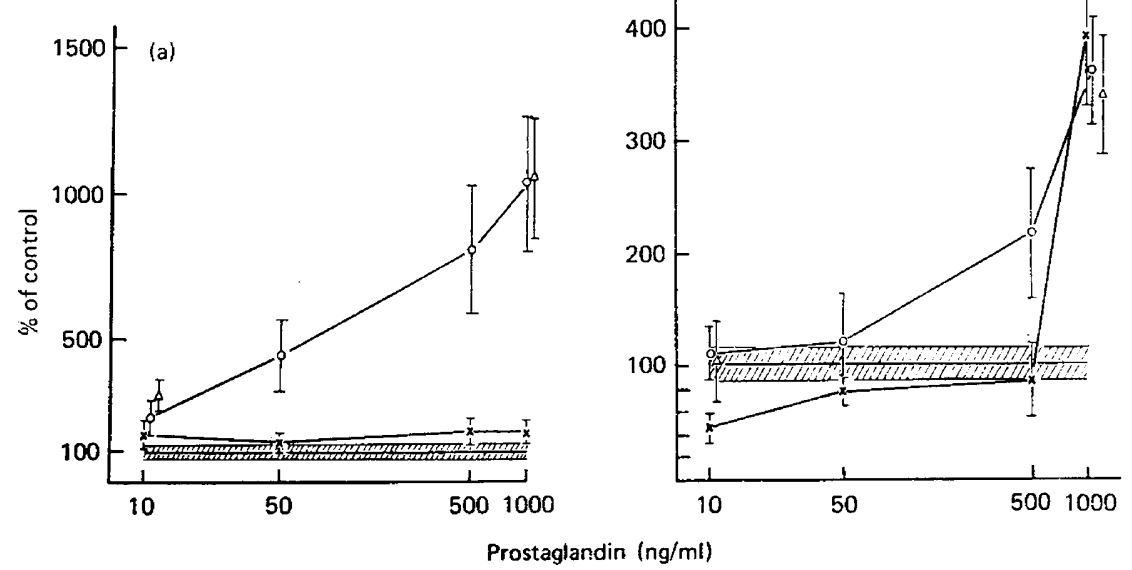

Text-fig. 1. The production of progesterone by mouse ovaries maintained in culture for $24 \mathrm{hr}$ and exposed to different concentrations of PGF-2 $\alpha(x)$, PGE-2 (O) or PGF-2 $\alpha+$ PGE-2 $(\triangle)$ in the (a) absence or (b) presence of $1 \mu \mathrm{g} \mathrm{LH}+1 \mu \mathrm{g}$ FSH. Each point represents the mean for 7 ovaries and the vertical bars the S.E.M. The hatched area represents the mean \pm S.E.M. control values $(56 \cdot 7 \pm 10 \cdot 9 \mathrm{ng} / \mathrm{ml})$.

the gonadotrophic effect. The inhibitory effect of low doses of PGF-2 $\alpha$ was similar to that observed with human, bovine or porcine granulosa cells in culture (Henderson \& McNatty, 1975; McNatty et al. 1975) and may be due to the plasma membrane receptors for PGE-2 being unable to discriminate between different PGs when they are present at pharmacological levels (Kuehl, 1974).

If PGF- $2 \alpha$ and PGE-2 both rise in follicular tissue following the 'LH surge' in the mouse, as they do in the rabbit (LeMaire, Yang, Behrman \& Marsh, 1973), the steroidogenic response in vitro is likely to be similar to the stimulatory effect of PGE-2 alone (Text-fig. 1). The stimulatory effect of PGE-2 in vivo may be minimal, however, since the follicle would have been exposed to high levels of gonadotrophins (Text-fig. 1b). PGE-2 may therefore modify the steroidogenic response of the follicle to LH and thus ensure that the full steroidogenic potential of the newly forming CL is expressed.

Some of the expenses incurred in this study were defrayed from a grant to T.G.B. from the Population Council, New York. K.P.McN. was the recipient of a New Zealand N.R.A.C. Fellowship. We thank Mr J. F. Beattie, Dr R. W. Kelly and Mr I. Swanston for the assays of LH, PGE-2 and PGF-2 $\alpha$, respectively; Dr K. K. Dighe for the progesterone antiserum; the National Institutes of Health, Bethesda, for gonadotrophins; and Upjohn \& Co., Kalamazoo for the prostaglandins.

\section{References}

Henderson, K.M. \& McNatty, K.P. (1975) A biochemical hypothesis to explain the mechanism of luteal regression. Prostaglandins 9, 779.

KueHL, F.A., JR (1974) Prostaglandins, cyclic nucleotides and cell function. Prostaglandins 5, 325-340.

LeMaire, W.J., YaNG, N.S.T., Behrman, H.R. \& MARSH, J.M. (1973) Preovulatory changes in the concentration of PG's in rabbit Graafian follicles. Prostaglandins 3, 367-376.

LINDNER, H.R., TSAFriri, A., LIEBERMAN, M.E., Zor, U., Koch, Y., Bauminger, S. \& BARneA, A. (1974a) Gonadotropin action on cultured Graafian follicles: induction of maturation division of the mammalian oocyte and differentiation of the luteal cell. Recent Prog. Horm. Res. 30, 79-138.

Lindner, H.R., Zor, U., Bauminger, S., Tsafriri, A., LAMPrecht, S., Koch, Y., ANTEbi, S. \& SchWartZ, A. (1974b) The use of prostaglandin synthetase inhibitors in the analysis of the role of prostaglandins in reproductive physiology. In Prostaglandin Synthetase Inhibitors, pp. 271-290. Eds. H. J. Robinson and J. R. Vane. Raven Press, New York.

MCNATTY, K.P. \& SAWERS, R.S. (1975) Relationship between the endocrine environment within the Graafian follicle and the subsequent rate of proges- 
terone secretion by human granulosa cells in vitro. J. Endocr. 66, 391-400.

MCNatty, K.P., Henderson, K.M. \& Sawers, R.S. (1975) Effects of prostaglandin F2 $\alpha$ and E2 on the production of progesterone by human granulosa cells in tissue culture. J. Endocr. 67, 391-400.
Neal, P., Baker, T.G., McNatty, K.P. \& ScaramuzzI, R.J. (1975) Influence of prostaglandins and human chorionic gonadotrophin on progesterone concentration and oocyte maturation in mouse ovarian follicles maintained in organ culture. $J$. Endocr. 65, 19-25.

Received 3 December 1975 